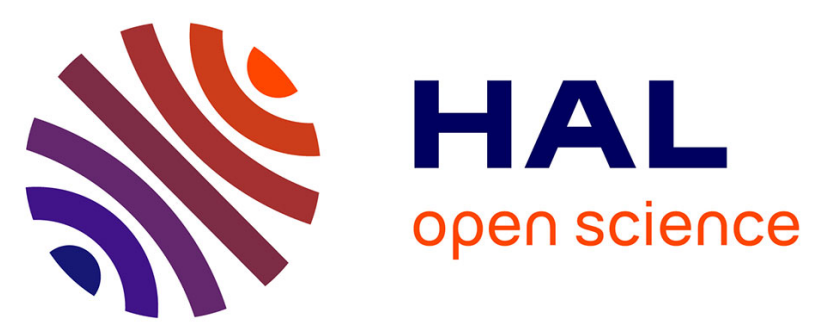

\title{
CORRELATION BETWEEN AGEING HEAT TREATMENTS, MICROSTRUCTURE AND STRESS CORROSION PROPERTIES OF Al-Li-Cu-Mg ALLOYS
}

Mumtaz Ahmad

\section{- To cite this version: \\ Mumtaz Ahmad. CORRELATION BETWEEN AGEING HEAT TREATMENTS, MICROSTRUC- TURE AND STRESS CORROSION PROPERTIES OF Al-Li-Cu-Mg ALLOYS. Journal de Physique Colloques, 1987, 48 (C3), pp.C3-871-C3-879. 10.1051/jphyscol:19873102 • jpa-00226536}

\author{
HAL Id: jpa-00226536 \\ https://hal.science/jpa-00226536
}

Submitted on 1 Jan 1987

HAL is a multi-disciplinary open access archive for the deposit and dissemination of scientific research documents, whether they are published or not. The documents may come from teaching and research institutions in France or abroad, or from public or private research centers.
L'archive ouverte pluridisciplinaire HAL, est destinée au dépôt et à la diffusion de documents scientifiques de niveau recherche, publiés ou non, émanant des établissements d'enseignement et de recherche français ou étrangers, des laboratoires publics ou privés. 


\title{
CORRELATION BETWEEN AGEING HEAT TREATMENTS, MICROSTRUCTURE AND STRESS CORROSION PROPERTIES OF AI-Li-Cu-Mg ALLOYS
}

\author{
M. AHMAD \\ Department of Mechanical Engineering, Linköping Institute of \\ Technology, S-581 83, Linköping, Sweden
}

\begin{abstract}
Stress corrosion cracking (SCC) behaviour of 8090 alloy (Al-Li-Cu-Mg) has been studied using precracked double cantilever beam (DCB) specimens and tuning fork type smooth test specimens. The alloy was SCC tested in several ageing conditions. Although stress corrosion cracks readily initiate when the alloy is exposed to $3.5 \% \mathrm{NaCl}$ environment, crack growth is difficult. The SCC performance of the 8090 alloy has been compared with that of 7075-T651 alloy. Fracture toughness of the alloy in a variety of ageing heat treatment conditions was determined by using chevron-notched short bar specimens. Ageing response of the alloy has been determined by hardness measurements and electrical conductivity measurements.
\end{abstract}

\section{Introduction}

Stress corrosion crack growth in aluminium alloys is strongly affected by composition and heat treatment (1). In 7000 series alloys, underaged and peakaged tempers are highly susceptible to $\mathrm{SCC}$, while overageing produces stress corrosion resistant alloys (1).

Recently, SCC of lithium-containing aluminium alloys have been the subject of number of papers (2-9). Work by Rinker et al (5) on alloy 2020 have shown that ageing the alloy from the underaged to the peak-aged condition results in significant reductions in the plateau velocity. This change in SCC behaviour was attributed to the potential difference between grain boundary $T_{1}$ precipitates and the grain interior. Christodoulou and co-workers (3) studied SCC of Al-Li binary alloys. It was suggested that hydrogen embrittlement may play a role in the SCC mechanism. Holroyd et al (6) investigated the SCC behaviour of binary $\mathrm{Al}-\mathrm{Li}$, ternary $\mathrm{Al}-\mathrm{Li}-\mathrm{Zr}$ and quarternary $\mathrm{A} 1-\mathrm{Li}-\mathrm{Cu}-\mathrm{Mg}$ alloys. Various mechanisms possibly involved in the stress corrosion cracking of Al-Li alloys were discussed.

The objective of the present work was to study the effects of complex ageing heat treatments on the fracture toughness and the stress corrosion resistance of the 8090 alloy.

\section{Materials and experimental procedures}

A $44 \mathrm{~mm}$ thick 8090 plate produced by British Alcan Aluminium was obtained. The as-received plate was in the peak aged condition i.e. aged for 16 hours at $190^{\circ} \mathrm{C}$. The chemical composition of the alloy plate is given in table 1.

Table 1

Chemical composition of 8090 alloy plate (by weight \%)

$\begin{array}{lllllll}\mathrm{Li} & \mathrm{Cu} & \mathrm{Mg} & \mathrm{Zr} & \mathrm{Fe} & \mathrm{Si} & \mathrm{Al} \\ 2.36 & 1.08 & 0.67 & 0.11 & 0.05 & 0.03 & \text { balance }\end{array}$


The plate was sawn along the rolling direction into bars with cross-section dimension of $44 \mathrm{~mm} \times 28 \mathrm{~mm}$. These bars were solution heat-treated in an air furnace for 1 hour at $530^{\circ} \mathrm{C}$, quenched in room temperature water, stretched 2.5 $\%$, and aged.

Fracture toughness tests were conducted on chevron-notched short bar specimens machined from the mid-thickness of plate. The geometry of short bar fracture toughness specimens has been described by Barker (10). The short bar specimens used in the present study were with a thickness, B of $25.4 \mathrm{~mm}$. They were loaded in a tensile testing machine with the help of suitable grips. A clip gage was mounted on the grips. The load and the load point opening displacement were recorded on an $\mathrm{X}-\mathrm{Y}$ plotter. This test procedure has been shown to provide toughness values for aluminium alloys that are closely related with the planestrain fracture toughness $\mathrm{K}_{\text {TC }}$ measured by the ASTM E 399 test method for toughness below $35 \mathrm{MPa}$ m (1f). Fracture toughness data are based on the average of two tests.

The short transverse stress corrosion resistance of the alloy was studied using smooth tuning fork type specimens (Fig. 1a) and precracked double cantilever beam (DCB) specimens (Fig. 1b). Tuning fork specimens were alternately immersed in a neutral $3.5 \%$ sodium chloride solution. Alternate immersion cycle was

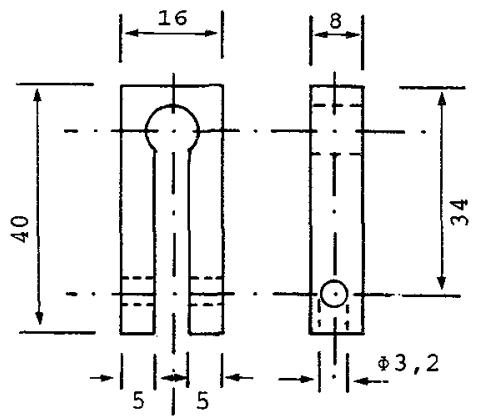

(a)

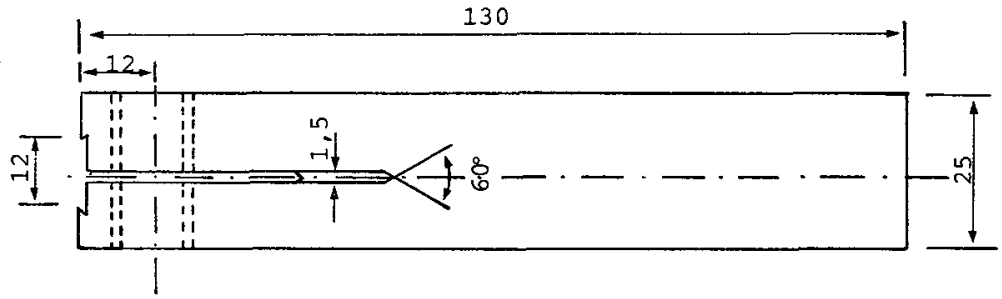

(b)

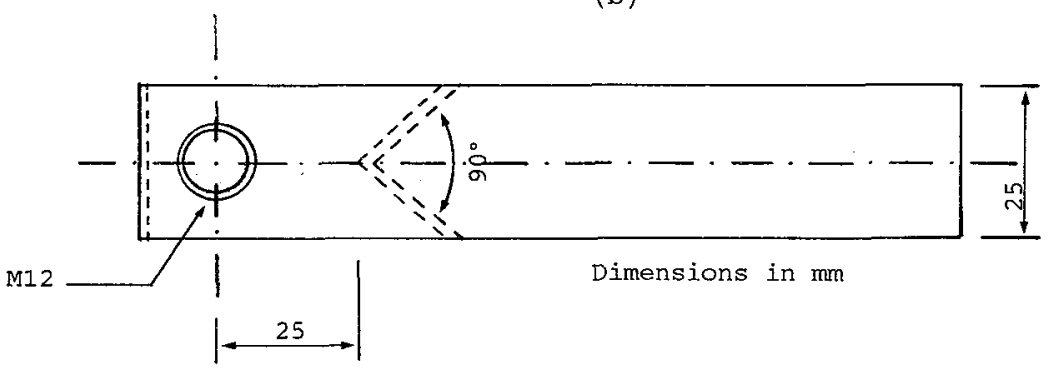

Fig. 1 Geometry of tuning fork (a) and double cantilever beam (b) specimens for SCC testing. 
accomplished such that the specimens were soaked in the solution for 10 minutes followed by a 50 minutes dry period in air. The specimens were inspected every second or every third day with a binocular at about $20 x$ magnification. A specimen was considered failed if a crack was evident at 20 times magnification. All the tuning fork specimens were initially loaded to a maximum stress of $120 \mathrm{MPa}$ with the help of steel bolts and a strain gage.

Stress corrosion crack propagation resistance of the alloy in the various ageing tempers was evaluated using DCB specimens. The size of the DCB specimens was chosen in accordance with recommendations made in ref. (12). The present design does not significantly differ from that of Hyatt (13). Specimens were fatigue precracked at $10 \mathrm{~Hz}$ and the maximum stress intensity was less than 80 percent of $\mathrm{K}_{\mathrm{IC}}$. Fatigue cycling continued until a crack had grown 2 to $2.5 \mathrm{~mm}$ beyond the 90 -degree chevron notch. A clip gage was attached and the specimens were bolt loaded to pre-determined starting stress intensity levels. Loaded specimens were placed vertical with the notched end up in a climatised room, and a few drops of $3.5 \% \mathrm{NaCl}$ solution were added to the notch once a hour with the help of a squeeze pump and plastic tubes. Crack lengths were measured optically (500X magnification) with the help of a travelling microscope on both sides of the specimen and the measurements averaged.

The following equation was used to calculate the stress intensity $\mathrm{K}_{\mathrm{I}}$ (12):

$$
K_{I}=\frac{\sqrt{3} E(2 V)}{4 \sqrt{H}\left(\frac{a}{H}+0,6728\right)}
$$

where $E$ = modulus of elasticity, $79 \mathrm{GPa}$ for 8090 alloy and $71.1 \mathrm{GPa}$ for 7075-T651 alloy.

$2 \mathrm{~V}=$ deflection of specimen arms at the load line.

$\mathrm{H}=1 / 2$ specimen height.

$a=$ crack length measured from the load line.

Results and Discussion

Fracture toughness

The various ageing treatments included in the investigation and corresponding hardness and electrical conductivity values are summarized in table 2 . Fracture toughness data of the alloy in different ageing conditions are also shown in table 2. The results show that fracture toughness decreases with ageing. This

Table 2

Results of fracture toughness tests.

$\begin{array}{lll}\text { Specimen Ageing of } & \text { Vickers Electrical } & \mathrm{K}_{\mathrm{SB}} \text { (a) } \\ \text { Number } 8090 \text { Alloy } & \text { Hardness Conductivity } & \text { (MPa)m }\end{array}$

(10 KP) (\% IACS)

\begin{tabular}{llrrr}
\hline 1 & $4 \mathrm{~h} / 190^{\circ} \mathrm{C}$ & 130.0 & 19.2 & 33.0 \\
2 & $16 \mathrm{~h} / 190^{\circ} \mathrm{C}$ & 142.9 & 19.5 & 16.0 \\
3 & $80 \mathrm{~h} / 190^{\circ} \mathrm{C}$ & 139.3 & 20.0 & 8.9 \\
5 & $190 \mathrm{~h} / 130^{\circ} \mathrm{C}$ & 133.1 & 19.4 & 34.8 \\
6 & $50 \mathrm{~h} / 130^{\circ} \mathrm{C}+16 \mathrm{~h} / 190^{\circ} \mathrm{C}$ & 137.1 & 19.3 & 19.2 \\
7 & $4 \mathrm{~min} / 250^{\circ} \mathrm{C}+16 \mathrm{~h} / 190^{\circ} \mathrm{C}$ & 141.7 & 19.4 & 13.7 \\
8 & as received $\left(16 \mathrm{~h} / 190^{\circ} \mathrm{C}\right)$ & 142.5 & 20.1 & 12.9 \\
$8 \mathrm{a}$ & as received $\left(16 \mathrm{~h} / 190^{\circ} \mathrm{C}\right)$ & - & - & 23.7 \\
9 & $7075-\mathrm{T} 651$ & - & 31.5 & -
\end{tabular}

(a) Fracture toughness test orientation was $S-L$, except the No. 8 a $(T-L)$. 
is typical for many other aluminium alloys with or without lithium (14-17). In addition it is seen that a slight improvement in fracture toughness of the alloy can be achieved by ageing at lower temperatures. This is consistent with the results of Curtis et al (18), Ashton et al (19) and Peel et al (20). Two different double ageing treatments (No. 6 and No. 7) included in the investigation did not show any significant improvement of the fracture toughness of the alloy at the peak strength level. The alloy specimen resolution treated and aged to the peak strength (No. 2) showed somewhat higher fracture toughness compared to the as-received condition (No. 8).

\section{Stress corrosion crack initiation}

The susceptibility to stress corrosion crack initiation was evaluated using smooth specimens of tuning fork tyje. The test results are presented in table 3. As can be seen, most of the Al-li specimens were failed within six days of testing. Al1 the specimens of the 7075 alloy and of the 8090 alloy aged for $190 \mathrm{~h}$ at $130^{\circ} \mathrm{C}$ survived 29 days alternate immersion in $3.5 \% \mathrm{NaCl}$ solution. The surviving 7075 alloy was severely pitted. However, the surface of aluminiumlithium alloy was clean and showed very little general corrosion. The Al-Li alloy aged $4 \mathrm{~h} / 190^{\circ} \mathrm{C}$ had the lowest resistance to stress corrosion crack iniation. The overaged temper $\left(80 \mathrm{~h} / 190^{\circ} \mathrm{C}\right)$ showed somewhat greater resistance to $\mathrm{SCC}$ initiation than the underaged $\left(4 \mathrm{~h} / 190^{\circ} \mathrm{C}\right)$ and the peak-aged $\left(16 \mathrm{~h} / 190^{\circ} \mathrm{C}\right)$ temper. However, there was a great deal of spread in the time to failure data of the overaged temper. Previously Reynolds and co-workers (21) reported that the period to crack iniation of the 8090 alloy can be significantly increased by overageing.

\section{Table 3}

Resistance to stress-corrosion cracking of 8090 and 7075-T651 alloy: Tuning fork smooth test specimens exposed to $3.5 \% \mathrm{NaCl}$ altenate immersion, short transverse stress $120 \mathrm{MPa}$.

\begin{tabular}{llll}
$\begin{array}{l}\text { Specimen } \\
\text { number }\end{array}$ & $\begin{array}{l}\text { Ageing } \\
\text { treatments }\end{array}$ & $\begin{array}{l}\text { Number } \\
\text { tested }\end{array}$ & $\begin{array}{l}\text { Faijure times, } \\
\text { days }\end{array}$ \\
\hline 1 & $4 \mathrm{~h} / 190^{\circ} \mathrm{C}$ & 2 & 2,6 \\
2 & $16 \mathrm{~h} / 190^{\circ} \mathrm{C}$ & 3 & $6,6,6$ \\
3 & $80 \mathrm{~h} / 190^{\circ} \mathrm{C}$ & $29,6,6$ \\
5 & $190 \mathrm{~h} / 130^{\circ} \mathrm{C}$ & 3 & $>29,>29,>29$ \\
6 & $50 \mathrm{~h} / 130^{\circ} \mathrm{C}+16 \mathrm{~h} / 190^{\circ} \mathrm{C}$ & 3 & $6,6,6$ \\
7 & $4 \mathrm{~min} / 250^{\circ} \mathrm{C}+16 \mathrm{~h} / 190^{\circ} \mathrm{C}$ & 3 & $6,6,6$ \\
8 & as received $\left(16 \mathrm{~h} / 190^{\circ} \mathrm{C}\right)$ & 3 & $6,8,8$ \\
9 & $7075-\mathrm{T} 651$ & 3 & $>10(\mathrm{a}),>29,>29$
\end{tabular}

(a) After 10 days of testing, exposure for one of the specimens was discontinued for metallographic examinations.

The tensile surfaces of tuning fork specimens after 10 days alternate immersion in aqueous $3.5 \% \mathrm{NaCl}$ solution are shown in $\mathrm{fig} 2$. Prior to photographing, the surface of the 7075 alloy specimen was chemically cleaned by using $65 \% \mathrm{HNO}_{3}$. The overaged specimen shows more pitting corrosion attack and multicrack initiation, while the underaged shows less pitting corrosion attack and a few. but longer stress corrosion cracks. The specimen pre-aged at the high temperature $\left(4 \mathrm{~min} / 250^{\circ} \mathrm{C}+16 \mathrm{~h} / 190^{\circ} \mathrm{C}\right)$ shows a single long crack that has grown across the width $(8 \mathrm{~mm})$ of the tuning fork specimen. After fracturing, it was observed that the stress corrosion attack in the above specimen was deeper compared to the other specimens aged differently. It has been reported that a similar two-step ageing treatment can improve SCC resistance of 2214 alloy (22). After 10 days of alternate immersion, some of the tuning fork specimens were sectioned in order to examine the type of corrosion attack. Optical photomicrographs of the cross section of the as-received 8090 alloy and the 
7075 alloy are shown in fig. 3. A typical intergranular type stress corrosion crack is seen in the 8090 alloy. The 7075 alloy shows severe corrosion pits but crack initiation has not occured.

\section{Stress corrosion crack propagation}

The stress corrosion crack growth versus exposure time curves are shown in fig. 4. The DCB specimens were made from the 8090 alloy given different ageing treatuents and the 7075-T651 alloy. Values of the starting stress intensity factor applied to the DCB specimens are listed in table 4 . It is evident from fig. 4 that total growth in the 7075 alloy is much higher compared to the 8090 alloy, even though the starting stress intensity factor for 7075-DCB specimen was slightly lower. An interesting feature of the crack extension curves for the aluminium-1ithium alloy is the occurrence of numerous steps. This indicates that crack growth in the aluminium-lithium alloy might be discontinuous.

Christodoulou et al (3) studied the SCC behaviour of the Al-2.8\% Li alloy. They noticed banded texture on the SCC-fracture surfaces and attributed it to the discontinuous crack propagation. It was suggested that hydrogen embrittlement may play a role in the cracking mechanism. Average growth rates based on a total exposure period of 22 days were calculated and the results are presented in table 4. The overaged specimen (No. 3) and the low temperature underaged (No. 5) did not show any measurable crack growth for six weeks of exposure. These two ageing treatinents performed better even in the smooth specimen stress corrosion tests. However, it should be noted that the threshold $\mathrm{K}_{\mathrm{IS}} \mathrm{C}$ for the overaged temper is rather low due to its lower fracture toughness 1 ( $8.9 \mathrm{MPa} / \mathrm{m})$. The specimens aged to the peak strength via different ageing treatments (No. 2, $6,7)$ had nearly the same average growth rates. The DCB specimens have so far been tested for 6 weeks. During this period total growth in the underaged Al-Li specimen (No. 1) is greater than the other Al-Li specimens. However, during the first one month of testing growth in the underaged specimen was slower than the other Al-Li peak aged specimens (No. 2, 6, 7). This early slow growth in the underaged specimen is probably due to its high fracture toughness.

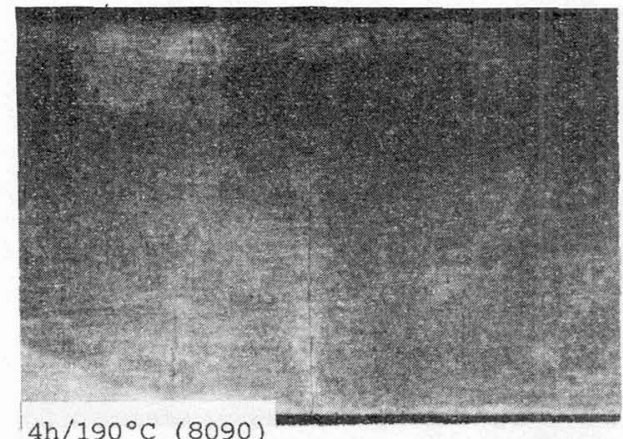

$4 \mathrm{~h} / 190^{\circ} \mathrm{C}(8090)$

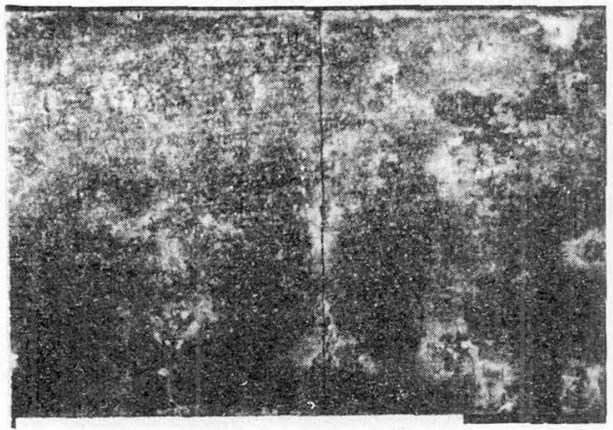

$4 \mathrm{~min} / 250^{\circ} \mathrm{C}+16 \mathrm{~h} / 190^{\circ} \mathrm{C}(809 \mathrm{C})$
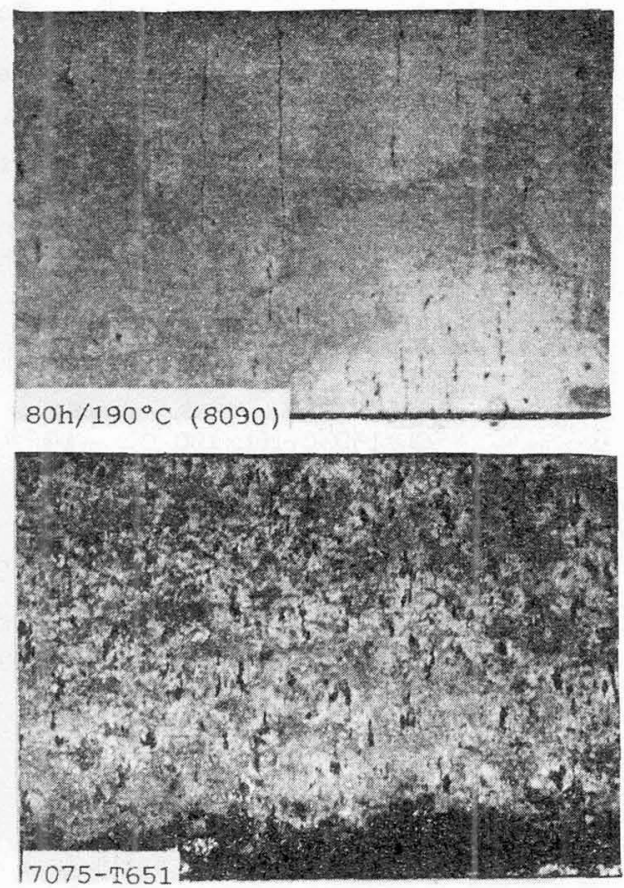

Fig. 2 The surface appearance of tuning fork smooth specimens after 10 days alternate immersion in aqueous $3.5 \% \mathrm{NaCl}$ solution. 


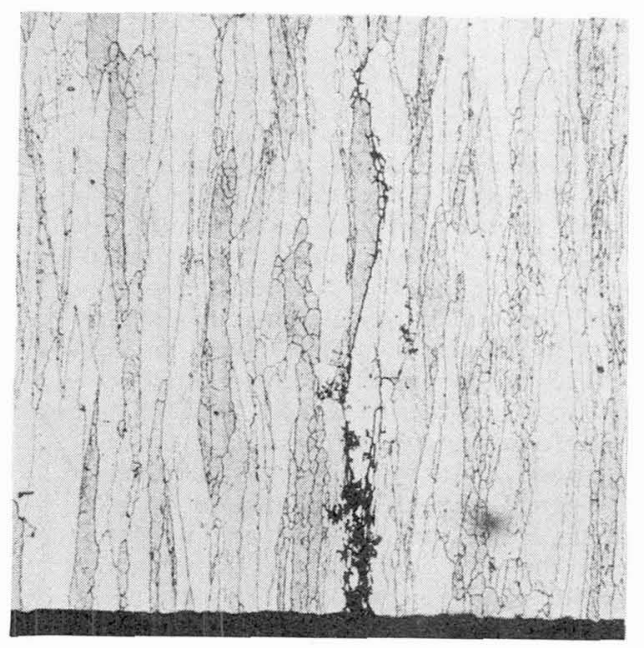

(a)

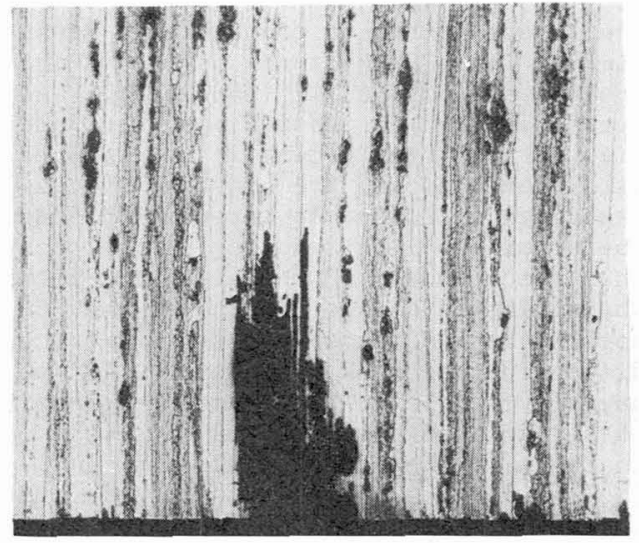

(b)

Fig. 3 Cross-section of the tuning fork specimens after 10 days alternate immersion in $3.5 \% \mathrm{NaCl}$ solution, (a) as-received 8090 alloy (No. 8 )

- stress corrosion crack , (b) 7075-T651 alloy - pitting corrosion.

Table 4

Stress corrosion crack propagation data of fatigue-precracked DCB specimens, periodic moistening with aqueous $3.5 \% \mathrm{NaCl}$ solution.

\begin{tabular}{llllll}
$\begin{array}{l}\text { Specimen } \\
\text { Number }\end{array}$ & $\begin{array}{l}\text { Ageing } \\
\text { treatments }\end{array}$ & $\begin{array}{l}\text { Initial } \\
\text { stress } \\
\text { intensity } \\
\text { (a) MPalm }\end{array}$ & $\begin{array}{l}\text { Final } \\
\text { stress } \\
\text { intensity } \\
\text { (b) MPalm }\end{array}$ & $\begin{array}{l}\text { Total } \\
\text { crack } \\
\text { growth } \\
\Delta a(m m)\end{array}$ & $\begin{array}{l}\text { Crack } \\
\text { growth } \\
\text { rate } \\
\mathrm{m} / \mathrm{s} \times\end{array}$ \\
\hline 1 & $4 \mathrm{~h} / 190^{\circ} \mathrm{C}$ & 14 & 13.9 & 0.20 & 1.05 \\
2 & $16 \mathrm{~h} / 190^{\circ} \mathrm{C}$ & 14 & 13.6 & 0.90 & 4.73 \\
3 & $80 \mathrm{~h} / 190^{\circ} \mathrm{C}$ & 7.5 & 7.5 & 0.110 & 0.58 \\
5 & $190 \mathrm{~h} / 130^{\circ} \mathrm{C}$ & 14 & 13.9 & 0.125 & 0.66 \\
6 & $50 \mathrm{~h} / 130^{\circ} \mathrm{C}+16 \mathrm{~h} / 190^{\circ} \mathrm{C}$ & 14 & 13.6 & 0.775 & 4.08 \\
7 & $4 \mathrm{~min} / 250^{\circ} \mathrm{C}+16 \mathrm{~h} / 190^{\circ} \mathrm{C}$ & 12.5 & 12.1 & 0.70 & 3.68 \\
9 & $7075-\mathrm{T} 651$ & 12.6 & 11.1 & 3.30 & 17.36
\end{tabular}

(a) Crack-tip stress intensity factor applied before environmental

(b) Crack-tip stress intensity factor after 22 days exposure.

(c) Average growth rate based on an exposure period of 22 days. 


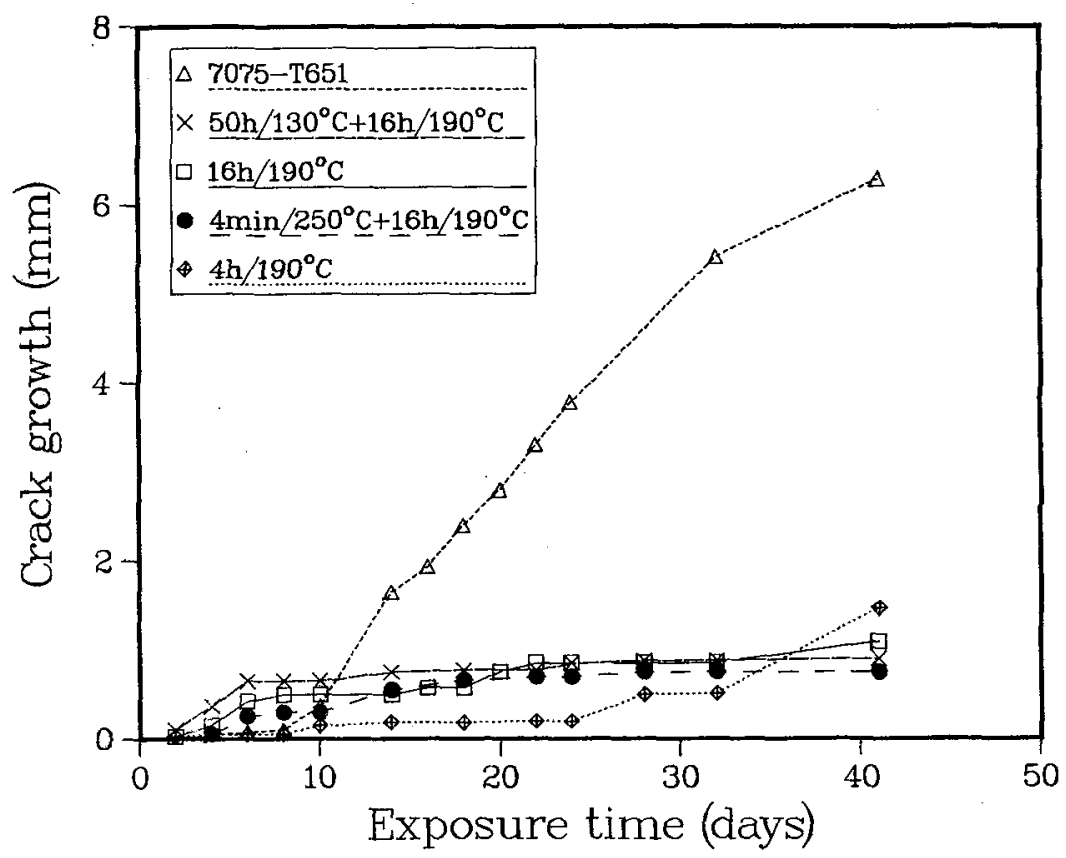

Fig. 4 Stress corrosion crack growth versus exposure time curves for the 8090 alloy in different ageing conditions and the 7075-T651 alloy. Periodic moistening with $3.5 \% \mathrm{NaCl}$ solution.

The low-temperature underaged specimen $\left(190 \mathrm{~h} / 130^{\circ} \mathrm{C}\right)$ showed best combination of fracture toughness and SCC. A possible explanation to this might be that at this low temperature $\left(130^{\circ} \mathrm{C}\right.$ ) particles of type $\mathrm{S}^{\prime}$ ( $\left.\mathrm{Al} \mathrm{C}_{2} \mathrm{CuMg}\right), \mathrm{T}_{1}$ ( $\mathrm{A1}{ }_{2} \mathrm{CuLi}$ ) and $\delta$ (A1Li) have not yet precipitated at grain boundaries and subgrain boundaries. It is known that $S^{\prime}$ and $\mathrm{T}_{1}$ particles preferentially precipitates at the grain and the subgrain boundaries in the early stages of ageing at $190^{\circ} \mathrm{C}$ (23). The underaged temper $\left(4 \mathrm{~h} / 190^{\circ} \mathrm{C}\right)$ is then expected to be more susceptible to SCC than the peak-aged and the overaged temper due to a greater potential difference between grain boundaries and the grain interior. There are some indications for that (Table 3 and Fig. 4), but the data gathered so far are too limited to make definite conclusion. Urushino et al (24) measured the pitting potential of 2024 alloy ( $\mathrm{Al}-\mathrm{Cu}-\mathrm{Mg}$ ) in a de-aerated IM NaCl solution. It was suggested that the dissolution of $\mathrm{S}\left(\mathrm{Al}_{2} \mathrm{CuMg}\right)$ phase should occur while SCC proceeds, but the important role in $\mathrm{SCC}^{2}$ of the alloy is played by the pitting dissolution of solute-denuded zones along the grain boundaries.

Testing on the DCB specimens is continuing. 'The scanning electron microscopic study on the fractured short bar specimens, and the TEM study of the microstructures are planned. More extended results will be published elsewhere.

\section{Conclusions}

The S-L fracture toughness of the 8090 alloy decreases with ageing at $190^{\circ} \mathrm{C}$ from $33 \mathrm{MPa} \mathrm{m}$ (underaged) to $8.9 \mathrm{MPa}$ m (overaged).

Stress corrosion cracks readily initiate in the underaged and peakaged temper of the 8090 alloy when exposed to $3.5 \% \mathrm{NaCl}$ alternate immersion. On the other hand equivalent exposure of the 7075-T651 alloy results in severe pitting attack but no SCC. 
3) From the stress corrosion crack growth studies on the DCB specimens it is concluded that the 8090 alloy is superior to the $7075-T 651$ alloy.

4)

A low-temperature underageing treatment $\left(190 \mathrm{~h} / 130^{\circ} \mathrm{C}\right)$ of 8090 alloy showed best combination of fracture toughness and SCC resistance.

\section{Acknowledgements}

The author would like to thank Alcan International Ltd for providing the 8090 alloy plate. The author would also like to thank $\mathrm{Dr}, \mathrm{B}$. Jaensson and $\mathrm{Mr}$. B. Svensson of Saab-Scania $A B$, Aircraft Division for conducting stress corrosion tests on tuning fork type specimens at their testing facility at Saab. Encouragement and support given by Prof. T. Ericsson and Dr. S. Johansson is gratefully acknowledged. The technical assistance of $\mathrm{Mr}$. N. Larsson is greatly appreciated. This research was funded by Saab-Scania AB, Aircraft Division and the National Swedish Board for Technical Development.

\section{References}

1. M. O. Speidel

Metall. Trans. A, 6A, 631 (1975)

2. P. Niskanen, T. H. Sanders, I. G. Rinker and M. Marek Corros. Sci., 22, 283 (1982)

3. L. Christodaoulou, L. Struble, and J. R. Pickens Aluminium-Lithium Alloys II, eds. T. H. Sanders and E. A. Starke, AIME, Warrendale, 1984, p 561

4. P. P. Pizzo, R. P. Galvin and H. G. Nelson in Ref. 3, p. 627

5. J. G. Rinker, M. Marek, and T. H. Sanders Mater. Sci. Eng., 64. 203 (1984)

6. N. J. Holroyd, A. Gray, G. M. Scamans, and R. Hermann Aluminium-Lithium Alloys III, (ed. C. Baker et al), The Institute of Metals, London, 1986 , p. 310

7. A. K. Vasudevan, P. R. Ziman, S. C. Jha, and T. H. Sanders in Ref. 6, p. 303

8. P. L. Lane, J. A. Gray, and C. J. E. Smith

in Ref. 6, p. 273

9. E. I. Meletis

in Corrosion Cracking, conference proceedings, ed. V. S. Goel, ASM, 1986, p. 315

10. L. M. Barker

Engng. Fracture Mech., 17, 289 (1983)

11. K. R. Brown

in Chevron-Notched Specimens: Testing and Stress Analysis, ASTM, STP 855, (1984), p. 237

12. D. 0. Sprowls

in Metals Handbook, ninth edition, volume 8, Mechanical Testing, ASM, (1985), p. 495

13. M. V. Hyatt

Corrosion, 26, 487 (1970)

14. G. T. Hahn, and A. R. Rosenfield

Metall. Trans. A, 6A, 653 (1975)

15. K. V. Jata, and E. A. Starke

Metall. Trans. A, 17A, 1011 (1986)

16. S. Suresh, A. K. Vasudevan, M. Tosten, and P. R. Howell Acta Metall., 35, 25 (1987)

17. R. C. Dorward

Mater. Sci. Eng., 84, 89 (1986)

18. R. E. Curtis, G. H. Narayanan, and W. E. Quist

European Patent No., EP 0150456 A2

19. R. F. Ashton, D. S. Thompson, E. A. Starke, and F. S. Lin in Ref. 6, p. 66 
20. C. J. Pee1, D. McDarmaid, and B. Evans

A paper presented at Westec conference, Márch 1987

21. M. A. Reynolds, A. Gray, E. Creed, R. M. Jordan, and A. P. Titchener in Ref. 6, p. 57

22. B. Dubost, J. Bouvaist, and M. Reboul

in "Aluminium Alloys - their physical and mechanical properties" eds

E. A. Starke and T. H. Sanders, 1986, Warley, Engineering Materials

Advisory Service

23. M. Ahmad, and T. Ericsson

in Ref. 6, p. 509

24. K. Urushino, and K. Sugimoto

Corros. Sci., 19, 225 (1979) 